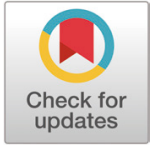

Received: Jun 4, 2020

Revised: Jul 21, 2020

Accepted: Jul 27, 2020

\#These authors contributed equally to this work.

${ }^{*}$ Corresponding author

Dong-Gyun Yim

Department of Agricultural

Biotechnology and Research Institute

of Agriculture and Life Sciences,

Seoul National University, Seoul 08826,

Korea.

Tel: +82-2-880-4820

E-mail: tousa0994@naver.com

Copyright (c) 2020 Korean Society of Animal Sciences and Technology.

This is an Open Access article distributed under the terms of the

Creative Commons Attribution

Non-Commercial License (http://

creativecommons.org/licenses/by-

$\mathrm{nc} / 4.0 /$ ) which permits unrestricted

non-commercial use, distribution, and

reproduction in any medium, provided

the original work is properly cited.

ORCID

Sang-Keun Jin

https://orcid.org/0000-0002-8983-5607

Teak-Soon Shin

https://orcid.org/0000-0001-5362-9206

Dong-Gyun Yim

https://orcid.org/0000-0003-0368-2847

Competing interests

No potential conflict of interest relevant

to this article was reported.

\section{Effects of partial substitution of nitrites with purple-fleshed sweet potato powder on physicochemical characteristics of sausages}

\author{
Sang-Keun $\operatorname{Jin}^{1 \#}$, Teak-Soon Shin ${ }^{2 \#}$ and Dong-Gyun Yim ${ }^{3 *}$ \\ ${ }^{1}$ Department of Animal Resources Technology, Gyeongnam National University of Science and \\ Technology, Jinju 52725, Korea \\ ${ }^{2}$ Department of Animal Science, Pusan National University, Miryang 50463, Korea \\ ${ }^{3}$ Department of Agricultural Biotechnology and Research Institute of Agriculture and Life Sciences, \\ Seoul National University, Seoul 08826, Korea
}

\begin{abstract}
Synthetic nitrite imparts a reddish-pink color to meat and a distinct flavor to meat products, delays lipid oxidation, and inhibits microbial growth and pathogens. However, excessive intake of nitrite might result in the production of carcinogenic nitrosamine, which might increase the risk of cancer in humans. Therefore, we aimed to find an alternative natural colorant for pork sausages. Pork sausages were mixed with $0.014 \%$ sodium nitrite $\left(\mathrm{NaNO}_{2}\right)$ alone $(\mathrm{CON})$, without either $\mathrm{NaNO}_{2}$ or purple-fleshed sweet potato powder (PP; CON1), 0.5\% PP alone (PP1), 1\% PP (PP2) alone, 0.011\% $\mathrm{NaNO}_{2}$ and $0.5 \%$ PP (SP1), and $0.011 \% \mathrm{NaNO}_{2}$ and $1 \%$ PP (SP2). The sausages were then cooked and stored for physicochemical analysis on days 0 , $5,10,15$, and 20 . The $a^{*}$ and $W^{*}$ values were the greatest and lowest in the SP2 and CON1 treatments, respectively $(p<0.05)$. The concentrations of residual nitrite in the sausages at 20 days decreased in the order of CON $>$ SP1, SP2 > PP2 > PP1, CON1. The fatty acid content was higher, and flavorous amino acids were more in PP2 $(p<0.05)$. The fatty acid composition was comparable between the SP2 and CON groups, but the contents of glutamic acid and alanine were greater in the SP2 group. In conclusion, SP2 $\left(0.011 \% \mathrm{NaNO}_{2}\right.$ with $1 \% \mathrm{PP}$ ) could be added as a natural colorant for pork sausage production, and $\mathrm{NaNO}_{2}$ could be substituted with up to $20 \%$ PP without detrimental effects on sausage appearance and/or quality.
\end{abstract}

Keywords: Purple sweet potato, Sausage, Nitrite, Physicochemical characteristic

\section{INTRODUCTION}

Synthetic nitrite imparts a reddish-pink color to meat and a distinct flavor to meat products, delays lipid oxidation, and inhibits microbial growth and pathogens [1,2]. However, the possible generation of carcinogenic nitrosamine due to excessive nitrite intake might be associated with an increased risk of cancer [3], which is an important concern in the meat industry. Consumers now prefer safe foods without synthetic ingredients or additives that might endanger health [4]. The development and utilization 
Funding sources

This work was supported in parts by Korea Institute of Planning and Evaluation for Technology in Food, Agriculture, Forestry and Fisheries (IPET) through High Value-added Food Technology Development Program, funded by Ministry of Agriculture, Food and Rural Affairs (MAFRA, 118039-03-1-HD020) and the 2020th RAIC Gyeongnam National University of Science and Technology in Korea.

Acknowledgements

Not applicable.

Availability of data and material Upon reasonable request, the datasets of this study can be available from the corresponding author.

Authors' contributions Conceptualization: Jin SK.

Data curation: Jin SK.

Formal analysis: Jin SK.

Methodology: Jin SK.

Software: Jin SK.

Validation: Shin TS.

Investigation: Shin TS.

Writing - original draft: Jin SK, Yim DG.

Writing - review \& editing: Jin SK, Yim DG.

Ethics approval and consent to participate This article does not require IRB/IACUC approval because there are no human and animal participants. of natural additives have recently attracted attention. Most natural additives that are used in sausages are sourced from herbs, spices, fruits, and vegetables [5].

Sweet potato (Ipomea batatas L.) is an abundant source of anthocyanins, vitamins, fiber, and minerals that can inhibit colon cancer, diverticular disease and constipation, decrease blood cholesterol, and help digestion [6-8]. Purple sweet potato is a source of abundant $\beta$-carotene, anthocyanins, and starch and has inherent water retention properties [9]. Anthocyanin and other polyphenols in purple sweet potatoes are powerful antioxidants [8], and anthocyanins can serve as a natural colorant, imparting a red-violet color to food [10]. However, only a few studies have addressed the impact of incorporating purple sweet potato powder (PP) on the physicochemical characteristics of sausages. Therefore, the present study aimed to determine whether PP could minimize the amount of sodium nitrite $\left(\mathrm{NaNO}_{2}\right)$ that is normally added to pork sausages without compromising quality, appearance and nutritional value.

\section{MATERIALS AND METHODS}

\section{Sample preparation}

Lean pork $(\sim 20 \mathrm{~kg})$ and its fat were taken from a butcher, then the meat was coarsely pulverized in a grinder (Model 200, Lasar, Los Angeles, CA, USA), and categorized into six treatments (3 kg/group).

\section{Preparation of cooked pork sausages}

Table 1 shows the amounts of additives mixed with the meat in each group as follows: $0.014 \%$ $\mathrm{NaNO}_{2}$ (Sewoo, Seoul, Korea), no $\mathrm{NaNO}_{2}$ or PP, 0.5\% PP, 1\% PP, 0.011\% $\mathrm{NaNO}_{2}$ and $0.5 \% \mathrm{PP}$

Table 1. Composition of cooked pork sausage blends ${ }^{1)}$

\begin{tabular}{lrrrrrr}
\hline \multirow{2}{*}{ Ingredients } & \multicolumn{7}{c}{ Composition (\%) } \\
\cline { 2 - 7 } & CON & CON1 & PP1 & PP2 & SP1 & SP2 \\
\hline Meat ingredients & & & & & & \\
$\quad$ Pork loin meat & 72.266 & 72.28 & 71.78 & 71.28 & 71.769 & 71.269 \\
Pork fat & 11.18 & 11.18 & 11.18 & 11.18 & 11.18 & 11.18 \\
Nonmeat ingredients & & & & & & \\
Ice & 13.78 & 13.78 & 13.78 & 13.78 & 13.78 & 13.78 \\
Salt & & & & & & \\
Sodium nitrite $\left(\mathrm{NaNO}_{2}\right)^{3)}$ & 1.4 & 1.4 & 1.4 & 1.4 & 1.4 & 1.4 \\
Phosphate $^{4)}$ & 0.014 & - & - & - & 0.011 & 0.011 \\
Sugar $^{5)}$ & 0.2 & 0.2 & 0.2 & 0.2 & 0.2 & 0.2 \\
MSG $^{6)}$ & 0.5 & 0.5 & 0.5 & 0.5 & 0.5 & 0.5 \\
Spice $^{7)}$ & 0.06 & 0.06 & 0.06 & 0.06 & 0.06 & 0.06 \\
Purple-fleshed sweet potato powder $_{\text {Total }}$ & 0.6 & 0.6 & 0.6 & 0.6 & 0.6 & 0.6 \\
\hline
\end{tabular}

${ }^{1)}$ Treatments: CON (control), $0.014 \%$ sodium nitrite; CON1 (control1); no sodium nitrite and purple-fleshed sweet potato powder combination; PP1, no sodium nitrite and $0.5 \%$ purple-fleshed sweet potato powder; PP2, no sodium nitrite and $1 \%$ purple-fleshed sweet potato powder; SP1, $0.011 \%$ sodium nitrite and $0.5 \%$ purple-fleshed sweet potato powder combination; SP2, $0.011 \%$ sodium nitrite and $1 \%$ purple-fleshed sweet potato powder combination.

${ }^{2)}$ Refined salt (Woo-II S\&F, Ulsan, Korea).

${ }^{3)}$ Sodium nitrite (Duksan, Gyeonggi, Korea).

${ }^{4)}$ FOS/ENR (Taewon Food, Gyeonggi, Korea).

${ }^{5)}$ Beksul white sugar (CJ cheiljedang, Incheon, Korea).

${ }^{6)}$ Monosodium L-Glutanate (Shinwon Chemical, Seoul, Korea)

${ }^{7)}$ Bologna (Taewon Food, Gyeonggi, Korea). 
(Jisanfood, Jinju, Korea), and, $0.011 \% \mathrm{NaNO}_{2}$ and $1 \%$ PP. The meat and additives were mixed for $120 \mathrm{sec}$ to obtain uniform distribution of the additives in an A-20 matrix (Ramon, Oiartzun, Spain).

Meat mixtures ( $160 \mathrm{~g}$ ) were stuffed into E-25 fibrous casings (Sewoo, Seoul, Korea) to result in $120 \mathrm{~mm}$ sausages. The sausages were cooked in a water bath $\left(100^{\circ} \mathrm{C}\right)$ until the core temperature reached $75^{\circ} \mathrm{C}$ and then cooled at $5^{\circ} \mathrm{C}$ for $59 \mathrm{~min}$. Each sausage was vacuum packed with polyvinyl chloride film (Krehalon UK, Beverley, UK). All experimental sausages were stored at $4^{\circ} \mathrm{C}$ for 0,5 , 10 , and 20 days and they were then analyzed on different days. The fatty acid and amino acid composition of the sausages was conducted on day 0 . Each treatment was replicated four times.

\section{Physicochemical analysis}

The color values for $\mathrm{L}^{*}$ (lightness), $\mathrm{a}^{*}$ (redness), and $\mathrm{b}^{*}$ (yellowness) were measured using colorimeter (CR-310, Minolta Inc., Tokyo Japan). It was standardized using a calibration plate ( $\mathrm{Y}=93.5, \mathrm{X}$ $=0.3132, y=0.3198)$. Color parameters are expressed as: Whiteness $(\mathrm{W})$ was calculated according to the following formula: $\mathrm{W}=\mathrm{L}^{*}-3 \mathrm{~b}^{*}$. Cooked sausages $(4 \mathrm{~g})$ were disrupted in distilled water $(36$ $\mathrm{mL}$ ) at 3,000×g for $30 \mathrm{~s}$ with a homogenizer (Ultra-Turrax T-50, IKA, Staufen, Germany). The $\mathrm{pH}$ of the sausages was conducted with a $\mathrm{pH}$ meter (Model 440, Mettler-Toledo GmbH, Greifensee, Switzerland). The water-holding capacity (WHC) of samples was measured as described by Joo [11], with modifications. Briefly, samples $(3.0 \mathrm{~g})$ of intact meat were placed between two thin plastic films on weighed using Whatman No. 1 filter papers (diameter, $11 \mathrm{~cm}$ ), then compressed for $5 \mathrm{~min}$ between Plexiglas plates with a $2.5 \mathrm{~kg}$ load. After removing all of the compressed meat samples, the damp filter paper and the plastic films were immediately weighed, and WHC (\%) was determined as:

WHC $(\%)=$

$\underline{\text { (Damp filter paper and plastic film weight) }- \text { (Filter paper and plastic film weight) }}$

Meat sample weight $\times 100$

Six $1.5 \times 1.5 \times 1.5 \mathrm{~cm}$ samples of cooked pork sausage were sheared with an Instron 3343 (US/ MX40, A\&D, Norwood, MA, USA) to provide a crosshead speed of $100 \mathrm{~mm} / \mathrm{min}$. The shear force values from each sample were obtained and expressed as $\mathrm{kg} / \mathrm{cm}^{2}$. Volatile basic nitrogen (VBN) was obtained with the method of Conway micropipette diffusion as modified by Pearson [12] is expressed as $\mathrm{mg}$ VBN/100 $\mathrm{g}$ of sausage. Residual nitrite was calculated using spectrophotometry as described by AOAC [13].

\section{Analysis of fatty acid content}

Total fat was extracted as described by Folch et al. [14]. Samples ( $5 \mathrm{~g})$ were thawed, and then lipids were extracted in chloroform/methanol (2:1) using BHT as an antioxidant [15]. Fatty acid methyl esters were quantified using an Agilent 7890N gas chromatograph (Agilent Technologies GmbH., Waldbronn, Germany) equipped with a flame ionization detector and fused silica capillary column $(40 \mathrm{~m}, 0.28 \mathrm{~mm}$ ) with $0.3 \mathrm{~mm}$ film thickness (Agilent Technologies $\mathrm{GmbH}$ ). The carrier gas was helium $(5 \mathrm{~mL} / \mathrm{min})$, and the injection volume was $1 \mu \mathrm{L}$. The temperature of the oven was initially kept at $190^{\circ} \mathrm{C}$ for $60 \mathrm{sec}$, then maintained at $280^{\circ} \mathrm{C}$ for $15 \mathrm{~min}$. Linoleic acid (C18:2) was the internal standard (catalog number H3500, Sigma-Aldrich, St. Louis, MO, USA). Contents of saturated fatty acids (SFA), monounsaturated fatty acids (MUFA), and polyunsaturated fatty acids (PUFA) are expressed as ratios (\%) of total fatty acids, and PUFA/SFA and n-6/n-3 ratios were counted. 


\section{Analysis of protein and free amino acid content}

Protein content was obtained with a slight modification of AOAC [13]. For analysis of free amino acids, a modification of the HPLC method described by Bidlingmeyer et al. [16] was given. The samples were delipidized by solvent extraction, then hydrolyzed with $6 \mathrm{~N} \mathrm{HCl}$ in vacuum-packed tubes for $23 \mathrm{~h}$ at $108^{\circ} \mathrm{C}$. The hydrolyzed amino acids were sedimented by centrifugation at 5,000×g, and dried under vacuum for at least $1.5 \mathrm{~h}$. The $\mathrm{pH}$ was adjusted by adding $20 \mathrm{~mL}$ of ethanol: water: triethylamine (2:2:1) and the samples were dried as described above. The samples were derivatized in $20 \mu \mathrm{L}$ of ethanol:water:triethylamine:phenylisothiocyanate (7:1:1:1) at room temperature $\left(26^{\circ} \mathrm{C}\right)$ for $10 \mathrm{~min}$, then dried under vacuum for at least $3 \mathrm{~h}$. The samples were resuspended in $200 \mu \mathrm{L}$ Pico Tag ${ }^{\circledR}$ diluent (Waters GmbH., Haan, Germany), then $8 \mu \mathrm{L}$ was injected into a Nova-Pak C18 HPLC column (60 Angstroms, $4 \mu \mathrm{m}, 3.9 \times 150 \mathrm{~mm}$; Waters $\mathrm{GmbH}$.) attached to a $1525 \mathrm{HPLC}$ (with binary gradient delivery, 717 auto-sampler and injector, 1500 column heater, and a 2487 dual wavelength $\mathrm{UV}$ detector). Amino acids were separated using buffers comprising sodium acetate $(\mathrm{pH}$ 6.4), EDTA 5,000 ppm, triethylamine (1:2,000), acetonitrile 6\% v/v (buffer A) and acetonitrile $60 \%$ $\mathrm{v} / \mathrm{v}$, and EDTA 5,000 ppm; buffer B). A control sample was analyzed with the samples before hydrolysis to ensure accuracy and reproducibility. Data were analyzed using Breeze software Z (Waters $\mathrm{GmbH})$.

\section{Sensory color score determination}

Seven panelists (age range 20-30 years) participated in sensory evaluations of the sausages at 5-day intervals during the 20 days of storage. All panelists were trained based on procedures published by $[17,18]$. The sausages were cook at $102^{\circ} \mathrm{C}$ for $4 \mathrm{~min}$. Samples of the sausages were then cut into $1.5 \times 1.5 \times 1.5 \mathrm{~cm}$ cubes, coded with three-digit numbers and served to the panelists. Color was assessed based on a 9-point scale from 0 (extremely dislike) to 9 (extremely like). Two consecutive tasting sessions of three treated samples and a control sample proceeded with a 10-min break in between.

\section{Statistical analysis}

Data were collected in duplicate from the sausage samples (3 replicates $\times 6$ samples $\times 3$ treatments). Treatments and storage days were analyzed using one-way analysis of variance (ANOVA) and Duncan's multiple range test. All data were statistically analyzed using the general linear model procedure of the SAS statistical package [19] (SAS Institute, Cary, NC, USA). Values with $p<0.05$ were considered statistically significant.

\section{RESULTS AND DISCUSSION}

Table 2 shows the impacts of $\mathrm{PP}$ on the color of sausages during storage (Fig. 1). Lightness and yellowness values were significantly higher in sausages treated with CON1 than with PP plus $\mathrm{NaNO}_{2}(\mathrm{SP} 1, \mathrm{SP} 2)$ and PP alone (PP1, PP2) $(p<0.05)$. Kim and RYu [20] also found lower L* and $b^{*}$ values in sausages containing $\mathrm{PP}$ and $\mathrm{NaNO}_{2}$ than in controls. The $\mathrm{CIE} \mathrm{a}^{*}$ values were positively affected by $\mathrm{PP}$ with $\mathrm{NaNO}_{2}$. The $\mathrm{CIE} \mathrm{a}^{*}$ values were the highest and lowest after storage for 20 days, respectively, in sausages with, not without, added $0.011 \% \mathrm{NaNO}_{2}$ and $1 \% \mathrm{PP}(p<0.05)$. The higher redness values in the sausages of SP1 and SP2 were due to synergistic effects between $\mathrm{NaNO}_{2}$ pigments derived from the $\mathrm{PP}$ and formed nitrosohemochrome, which resulted in a pinkred color during cooking [21]. This difference in meat color might be due to the non-enzymatic browning reaction between sugars in the $\mathrm{PP}$ and meat protein [22]. These results of including $\mathrm{PP}$ as a $\mathrm{NaNO}_{2}$ replacement in sausages are consistent with those of Lee et al. [23]. Adding both sodium 
Table 2. Color characteristics of cooked pork sausages containing two different percentages of purple sweet potato combined with nitrite during storage

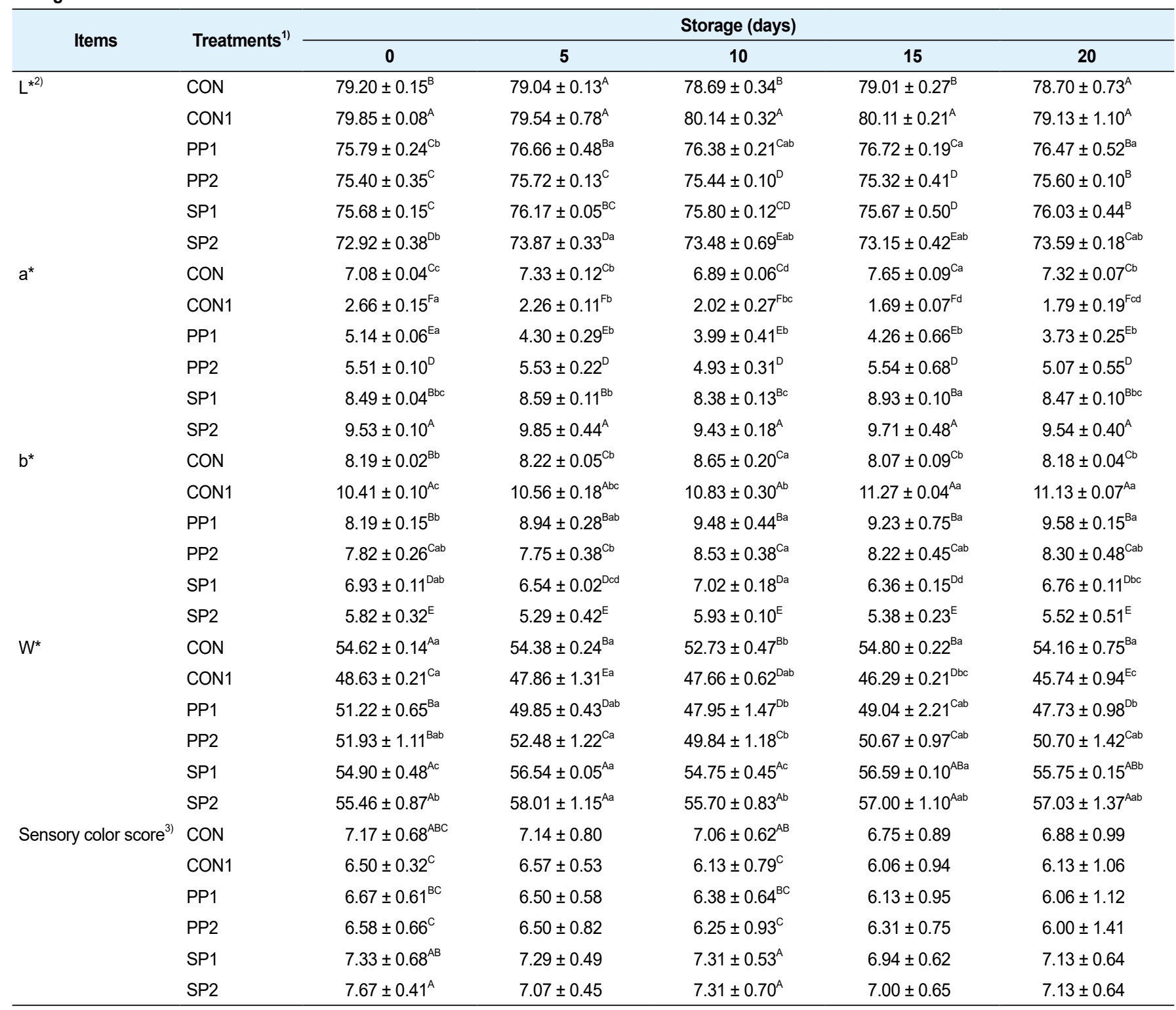

Data represent mean $\pm \mathrm{SD}$.

${ }^{1)}$ Treatments: CON (control), $0.014 \%$ sodium nitrite; CON1 (control1),no sodium nitrite and purple-fleshed sweet potato powder combination; PP1, no sodium nitrite and 0.5\% purple-fleshed sweet potato powder; PP2, no sodium nitrite and 1\% purple-fleshed sweet potato powder; SP1, 0.011\% sodium nitrite and $0.5 \%$ purple-fleshed sweet potato powder combination; SP2, $0.011 \%$ sodium nitrite and $1 \%$ purple-fleshed sweet potato powder combination.

${ }^{2)} \mathrm{W}=\mathrm{L}^{*}-3 \mathrm{~b}^{*}$.

${ }^{3)}$ Sensory color score were evaluated based on a 9-point scale, $0=$ extremely dislike and $9=$ extremely like.

${ }^{A-F}$ Means in the same column within the same aging period with different letters are significantly different $(p<0.05)$.

${ }^{a-d}$ Means in the same row within the same aging condition with different letters are significantly different $(p<0.05)$.

nitrite and PP affected the whiteness values of the sausages, because the SP1 and SP2 samples were whiter than all other treated samples $(p<0.05)$. These results agreed with those of Jin et al. [24], who showed that adding $\mathrm{NaNO}_{2}$ positively affected sausage whiteness. As shown in Fig. 1, color significantly differed between 0 and 10 days of storage, as panelists favored SP1 and SP2 to CON1, PP1, and PP2 $(p<0.05)$. 


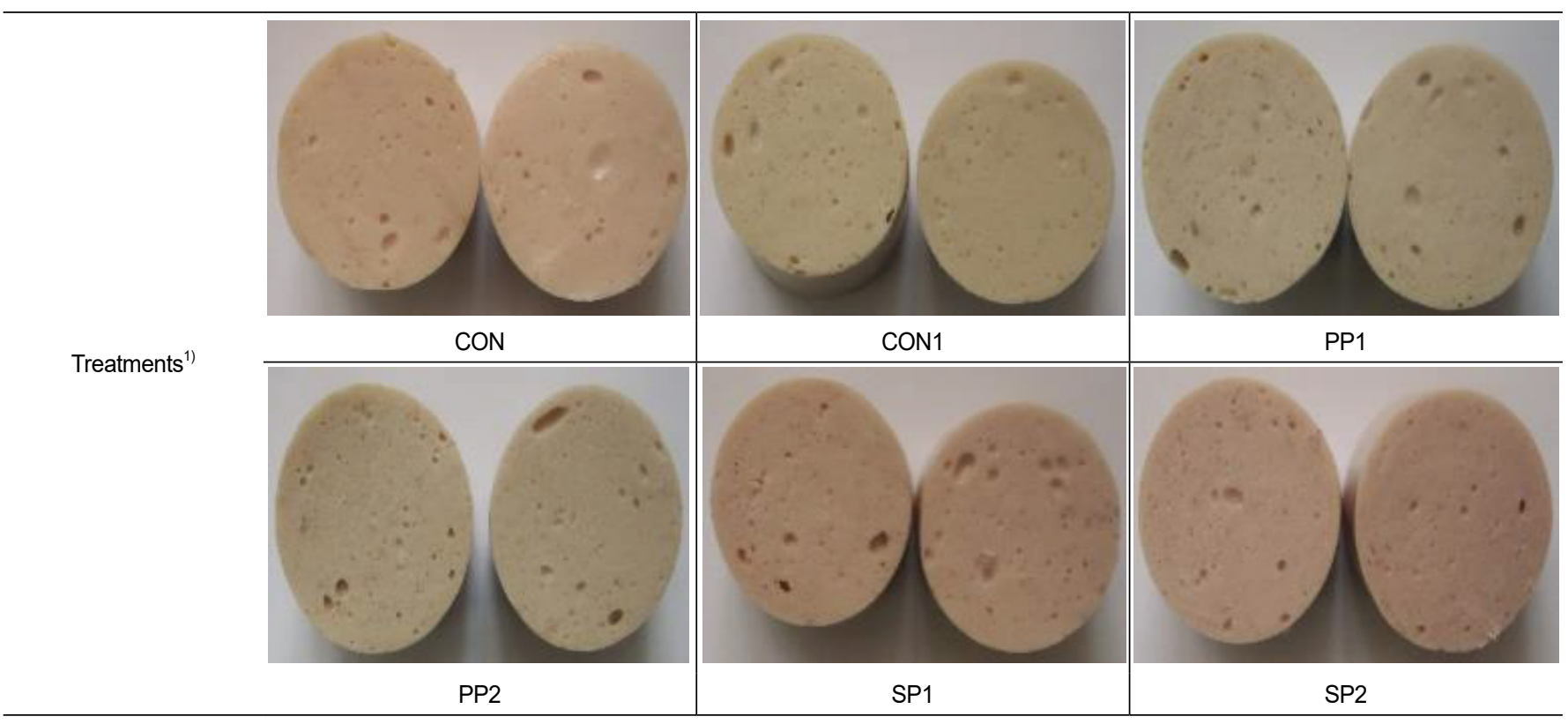

Fig. 1. Section color of cooked pork sausages containing two different percentages of purple sweet potato combined with nitrite. ${ }^{11}$ Treatments: CON (control), $0.014 \%$ sodium nitrite; CON1 (control1), no sodium nitrite and purple-fleshed sweet potato powder combination; PP1, no sodium nitrite and 0.5\% purple-fleshed sweet potato powder; PP2, no sodium nitrite and $1 \%$ purple-fleshed sweet potato powder; SP1, $0.011 \%$ sodium nitrite and $0.5 \%$ purple-fleshed sweet potato powder combination; SP2, $0.011 \%$ sodium nitrite and $1 \%$ purple-fleshed sweet potato powder combination.

Table 3 highlights the effects of adding $\mathrm{PP}$ on the physicochemical characteristics and $\mathrm{NaNO}_{2}$ retention in sausages during storage. The $\mathrm{pH}$ values were lower in sausages with added $\mathrm{PP}(p<0.05)$, which concurred with the findings of $[24,25]$. The decrease in the $\mathrm{pH}$ value of sausages containing PP might be due to the depolymerization of starch granules caused by cooking, resulting in acidic terminal residues in starch molecules [26]. A lower $\mathrm{pH}$ causes an acidic environment in sausages, thus suppressing bacterial growth [27]. In this study, the $\mathrm{pH}$ of sausages was affected by the addition of PP. Furthermore, the $\mathrm{pH}$ of the $\mathrm{PP}$ samples slightly increased over time in storage $(p<$ 0.05). The VBN content was comparable between the SP2 and CON groups, and lower in the PP2 than in the CON group on days 10 and $20(p<0.05)$. These findings agree with those of [23,24]. The low VBN values in the sausages were due to antimicrobial properties of PP. However, dramatic results were not observed in VBN measurement of this study. Our study found that the addition of PP might delay or inhibit spoilage (as indicated by VBN) in sausages. However, further study is needed.

All samples with added $\mathrm{NaNO}_{2}$ retained the most nitrite by day 20 (CON, SP1, and SP2) (Table 3). The concentration of residual nitrite in sausages at 20 days decreased in the order of $\mathrm{CON}>\mathrm{SP} 1$ and $\mathrm{SP} 2>\mathrm{PP} 2>\mathrm{PP} 1$ and CON1. More residual nitrite was found in the CON than in the SP1 and SP2 samples on day 20 of storage $(p<0.05)$. Levels of residual nitrite were significantly lower in samples containing both $\mathrm{PP}$ and added $\mathrm{NaNO}_{2}$, which concurred with the results of Lee et al. [23]. Marco et al. [28] found that the amount of nitrite in sausages rapidly decreases, owing to the higher reactivity of added nitrite compared with added nitrate. Thus, a low $\mathrm{pH}$ can affect the reactivity of nitrite and decrease the amount of residual nitrite in stored sausages. The present study also found decreased residual nitrite content in sausages with added PP during prolonged storage.

Table 4 describes the influence of PP on the fatty acid composition of sausages. Most of the detected fatty acids were MUFA, but the PUFA oleic acid (C18:1) was the most abundant in all treated samples. Saturated fatty acids were the next most abundant, with palmitic acid as its major 
Table 3. Physico-chemical traits and residual nitrite of cooked pork sausages containing two different percentages of purple sweet potato combined with nitrite during storage

\begin{tabular}{|c|c|c|c|c|c|c|}
\hline \multirow{2}{*}{ Items } & \multirow{2}{*}{ Treatments ${ }^{11}$} & \multicolumn{5}{|c|}{ Storage (days) } \\
\hline & & 0 & 5 & 10 & 15 & 20 \\
\hline \multirow[t]{6}{*}{$\overline{\mathrm{pH}}$} & CON & $6.06 \pm 0.01^{\mathrm{Ad}}$ & $6.07 \pm 0.00^{\mathrm{Dd}}$ & $6.16 \pm 0.02^{A b}$ & $6.26 \pm 0.02^{\mathrm{Aa}}$ & $6.10 \pm 0.01^{\mathrm{cc}}$ \\
\hline & CON1 & $6.03 \pm 0.01^{\mathrm{ABd}}$ & $6.12 \pm 0.01^{\mathrm{Bb}}$ & $6.16 \pm 0.01^{\mathrm{Aa}}$ & $6.12 \pm 0.00^{\mathrm{Db}}$ & $6.10 \pm 0.01^{\mathrm{cc}}$ \\
\hline & PP1 & $6.01 \pm 0.01^{\mathrm{Bc}}$ & $6.05 \pm 0.01^{\mathrm{Eb}}$ & $6.08 \pm 0.01^{\mathrm{Ca}}$ & $6.08 \pm 0.01^{\mathrm{Ea}}$ & $6.08 \pm 0.01^{\mathrm{Da}}$ \\
\hline & PP2 & $6.01 \pm 0.01^{\mathrm{Bc}}$ & $6.04 \pm 0.00^{\mathrm{Ec}}$ & $6.09 \pm 0.01^{\mathrm{Ca}}$ & $6.09 \pm 0.01^{\mathrm{Da}}$ & $6.09 \pm 0.01^{\mathrm{Da}}$ \\
\hline & SP1 & $6.04 \pm 0.02^{A B C}$ & $6.17 \pm 0.01^{\mathrm{Aa}}$ & $6.11 \pm 0.01^{\mathrm{Bb}}$ & $6.11 \pm 0.01^{\mathrm{Db}}$ & $6.18 \pm 0.02^{\mathrm{Aa}}$ \\
\hline & SP2 & $6.05 \pm 0.04^{\mathrm{Ac}}$ & $6.10 \pm 0.01^{\mathrm{cb}}$ & $6.15 \pm 0.00^{\mathrm{Aa}}$ & $6.14 \pm 0.00^{\mathrm{ca}}$ & $6.12 \pm 0.02^{\mathrm{Bab}}$ \\
\hline \multirow[t]{6}{*}{ WHC (\%) } & CON & $79.04 \pm 2.39^{\mathrm{Aa}}$ & $68.84 \pm 0.05^{\mathrm{Db}}$ & $70.95 \pm 2.10^{\mathrm{Bb}}$ & $52.87 \pm 0.62^{\mathrm{Cc}}$ & $71.68 \pm 1.52^{b}$ \\
\hline & CON1 & $74.99 \pm 0.44^{\mathrm{BCa}}$ & $70.48 \pm 0.96^{\mathrm{CDb}}$ & $71.04 \pm 2.20^{\mathrm{Bb}}$ & $61.74 \pm 1.59^{\mathrm{Ac}}$ & $72.58 \pm 0.54^{\mathrm{ab}}$ \\
\hline & PP1 & $68.90 \pm 2.34^{\mathrm{Db}}$ & $72.17 \pm 0.98^{\mathrm{BCa}}$ & $74.48 \pm 2.36^{\mathrm{ABa}}$ & $56.24 \pm 1.34^{\mathrm{BC}}$ & $72.52 \pm 0.42^{\mathrm{a}}$ \\
\hline & PP2 & $72.32 \pm 0.88^{\mathrm{Cb}}$ & $73.67 \pm 0.71^{\mathrm{ABab}}$ & $75.78 \pm 1.79^{\mathrm{Aa}}$ & $57.17 \pm 2.06^{\mathrm{BC}}$ & $73.66 \pm 1.00^{\mathrm{ab}}$ \\
\hline & SP1 & $73.80 \pm 0.76^{\mathrm{BCa}}$ & $70.55 \pm 1.40^{\mathrm{CDb}}$ & $71.82 \pm 1.74^{\mathrm{Bab}}$ & $58.77 \pm 1.15^{\mathrm{BC}}$ & $71.78 \pm 0.61^{\mathrm{ab}}$ \\
\hline & $\mathrm{SP} 2$ & $75.75 \pm 0.70^{\mathrm{Ba}}$ & $75.43 \pm 1.40^{\mathrm{Aa}}$ & $73.95 \pm 0.52^{\mathrm{ABab}}$ & $58.24 \pm 1.60^{\mathrm{BC}}$ & $72.16 \pm 0.45^{b}$ \\
\hline \multirow[t]{6}{*}{ Shear force $\left(\mathrm{kg} / \mathrm{cm}^{2}\right)$} & $\mathrm{CON}$ & $1.34 \pm 0.04^{\mathrm{bc}}$ & $1.27 \pm 0.14^{c}$ & $1.25 \pm 0.02^{\mathrm{Dc}}$ & $1.47 \pm 0.04^{\mathrm{Cab}}$ & $1.50 \pm 0.10^{\mathrm{Ca}}$ \\
\hline & CON1 & $1.36 \pm 0.12^{c}$ & $1.36 \pm 0.04^{c}$ & $1.64 \pm 0.04^{\mathrm{Ab}}$ & $1.43 \pm 0.05^{\mathrm{Cc}}$ & $1.91 \pm 0.08^{\mathrm{Aa}}$ \\
\hline & PP1 & $1.47 \pm 0.06^{\mathrm{bc}}$ & $1.40 \pm 0.05^{c}$ & $1.40 \pm 0.06^{\mathrm{Cc}}$ & $1.54 \pm 0.11^{\mathrm{BCb}}$ & $1.85 \pm 0.05^{\mathrm{ABa}}$ \\
\hline & PP2 & $1.38 \pm 0.06^{c}$ & $1.39 \pm 0.06^{c}$ & $1.55 \pm 0.03^{\mathrm{Bb}}$ & $1.58 \pm 0.02^{\mathrm{Bab}}$ & $1.67 \pm 0.08^{\mathrm{BCa}}$ \\
\hline & SP1 & $1.44 \pm 0.09^{b}$ & $1.38 \pm 0.15^{b}$ & $1.43 \pm 0.02^{\mathrm{Cb}}$ & $1.53 \pm 0.07^{\mathrm{BCb}}$ & $1.96 \pm 0.05^{\mathrm{Aa}}$ \\
\hline & SP2 & $1.40 \pm 0.06^{b}$ & $1.38 \pm 0.07^{b}$ & $1.37 \pm 0.03^{\mathrm{Cb}}$ & $1.73 \pm 0.03^{\mathrm{Aa}}$ & $1.84 \pm 0.16^{\mathrm{Aa}}$ \\
\hline \multirow[t]{6}{*}{ VBN (mg\%) } & CON & $4.20 \pm 0.28^{\mathrm{Aa}}$ & $2.99 \pm 0.16^{c}$ & $3.17 \pm 0.16^{\mathrm{ABbc}}$ & $3.45 \pm 0.16^{b}$ & $3.36 \pm 0.28^{A b c}$ \\
\hline & CON1 & $3.73 \pm 0.16^{\mathrm{ABa}}$ & $2.89 \pm 0.16^{b}$ & $3.08 \pm 0.00^{\mathrm{Bb}}$ & $3.08 \pm 0.28^{b}$ & $2.99 \pm 0.16^{\mathrm{ABb}}$ \\
\hline & PP1 & $3.17 \pm 0.16^{\mathrm{Bab}}$ & $2.71 \pm 0.16^{c}$ & $3.45 \pm 0.16^{\mathrm{Aa}}$ & $3.36 \pm 0.28^{\mathrm{a}}$ & $2.89 \pm 0.32^{\mathrm{Bbc}}$ \\
\hline & PP2 & $3.36 \pm 0.28^{\mathrm{Ba}}$ & $2.80 \pm 0.28^{\mathrm{b}}$ & $2.61 \pm 0.16^{\mathrm{Cb}}$ & $3.08 \pm 0.28^{\mathrm{ab}}$ & $2.89 \pm 0.16^{\mathrm{Bb}}$ \\
\hline & SP1 & $4.11 \pm 0.81^{\mathrm{Aa}}$ & $2.99 \pm 0.32^{b}$ & $2.99 \pm 0.16^{\mathrm{Bb}}$ & $3.17 \pm 0.16^{b}$ & $3.08 \pm 0.00^{\mathrm{ABb}}$ \\
\hline & SP2 & $3.27 \pm 0.16^{\mathrm{Bab}}$ & $2.89 \pm 0.16^{b}$ & $3.08 \pm 0.28^{\mathrm{Bab}}$ & $3.36 \pm 0.28^{a}$ & $3.17 \pm 0.16^{\mathrm{ABab}}$ \\
\hline \multirow[t]{6}{*}{ Residual nitrite (ppm) } & CON & $13.35 \pm 0.62^{\mathrm{A}}$ & ND & ND & ND & $11.64 \pm 1.40^{A}$ \\
\hline & CON1 & $4.31 \pm 1.16^{B}$ & ND & ND & ND & $3.72 \pm 0.63^{\mathrm{D}}$ \\
\hline & PP1 & $6.77 \pm 2.59^{\mathrm{B}}$ & ND & ND & ND & $3.54 \pm 0.77^{\mathrm{D}}$ \\
\hline & PP2 & $5.62 \pm 1.34^{B}$ & ND & ND & ND & $6.91 \pm 0.25^{\mathrm{C}}$ \\
\hline & SP1 & $12.85 \pm 0.88^{\mathrm{Aa}}$ & ND & ND & ND & $9.83 \pm 0.17^{\mathrm{Bb}}$ \\
\hline & SP2 & $15.37 \pm 0.42^{\mathrm{Aa}}$ & ND & ND & ND & $10.23 \pm 0.20^{\mathrm{Bb}}$ \\
\hline
\end{tabular}

Data represent mean \pm SD.

${ }^{1)}$ Treatments: CON (control), $0.014 \%$ sodium nitrite; CON1 (control1), no sodium nitrite and purple-fleshed sweet potato powder combination; PP1, no sodium nitrite and 0.5\% purple-fleshed sweet potato powder; PP2, no sodium nitrite and 1\% purple-fleshed sweet potato powder; SP1, 0.011\% sodium nitrite and 0.5\% purple-fleshed sweet potato powder combination; SP2, $0.011 \%$ sodium nitrite and $1 \%$ purple-fleshed sweet potato powder combination.

${ }^{A-D}$ Means in the same column within the same aging period with different letters are significantly different $(p<0.05)$.

${ }^{a-d}$ Means in the same row within the same aging condition with different letters are significantly different $(p<0.05)$.

component. The most abundant PUFA was linoleic acid. The PP2 sausages had the most PUFA, essential fatty acids (EFA), unsaturated fatty acids (UFA), ratios of UFA to SFA and of EFA to UFA, $n-3$ and $n-6$ fatty acids among the treated samples $(p<0.05)$. However, the composition of major fatty acids did not significantly differ between the CON and SP2 groups. A lower ratio (\%) of SFA in the PP2 samples was responsible for the reduced amount of palmitic and stearic acids, which are associated with an increased risk of cardiovascular disease [29]. The most abundant fatty acid in the PP2 samples was linoleic acid (C18:2n-6), which differed from all other samples. Many studies have shown that replacing dietary saturated fat with oils abundant in linoleic acid helps to 
Table 4. Fat and fatty acid composition of cooked pork sausages containing two different percentages of purple sweet potato combined with nitrite

\begin{tabular}{|c|c|c|c|c|c|c|}
\hline & \multicolumn{6}{|c|}{ Treatments $^{1)}$} \\
\hline & CON & CON1 & PP1 & PP2 & SP1 & SP2 \\
\hline Fat & $8.84 \pm 0.51$ & $8.77 \pm 0.54$ & $8.41 \pm 0.37$ & $8.53 \pm 0.35$ & $8.23 \pm 0.37$ & $8.45 \pm 0.27$ \\
\hline Capric acid (C10:0) & $0.07 \pm 0.00$ & $0.07 \pm 0.00$ & $0.07 \pm 0.00$ & $0.07 \pm 0.00$ & $0.07 \pm 0.00$ & $0.07 \pm 0.00$ \\
\hline Lauric acid (C12:0) & $0.09 \pm 0.01$ & $0.09 \pm 0.00$ & $0.09 \pm 0.00$ & $0.09 \pm 0.01$ & $0.09 \pm 0.00$ & $0.10 \pm 0.01$ \\
\hline Myristic acid (C14:0) & $1.69 \pm 0.01^{\mathrm{A}}$ & $1.62 \pm 0.01^{\mathrm{C}}$ & $1.57 \pm 0.01^{\mathrm{D}}$ & $1.59 \pm 0.00^{\mathrm{D}}$ & $1.65 \pm 0.01^{\mathrm{B}}$ & $1.59 \pm 0.03^{D}$ \\
\hline pentadecanoic acid (C15:0) & $0.09 \pm 0.00^{A}$ & $0.09 \pm 0.00^{A}$ & $0.08 \pm 0.00^{C}$ & $0.08 \pm 0.01^{\mathrm{BC}}$ & $0.09 \pm 0.01^{A B}$ & $0.08 \pm 0.00^{C}$ \\
\hline palmitic acid (C16:0) & $23.93 \pm 0.06^{A}$ & $22.76 \pm 0.09^{\mathrm{D}}$ & $22.68 \pm 0.10^{\mathrm{D}}$ & $22.62 \pm 0.01^{\mathrm{D}}$ & $23.71 \pm 0.03^{B}$ & $23.30 \pm 0.19^{C}$ \\
\hline Palmitoleic acid (C16:1) & $2.86 \pm 0.01^{\mathrm{A}}$ & $2.81 \pm 0.01^{B}$ & $2.63 \pm 0.02^{\mathrm{F}}$ & $2.77 \pm 0.01^{\mathrm{C}}$ & $2.71 \pm 0.01^{\mathrm{D}}$ & $2.68 \pm 0.02^{\mathrm{E}}$ \\
\hline Magaric acid (C17:0) & $0.43 \pm 0.00^{C}$ & $0.43 \pm 0.01^{c}$ & $0.45 \pm 0.01^{\mathrm{B}}$ & $0.42 \pm 0.00^{\mathrm{D}}$ & $0.47 \pm 0.00^{A}$ & $0.47 \pm 0.00^{A}$ \\
\hline Magaolic acid (C17:1) & $0.48 \pm 0.00^{B}$ & $0.48 \pm 0.01^{\mathrm{B}}$ & $0.48 \pm 0.01^{\mathrm{B}}$ & $0.48 \pm 0.01^{\mathrm{B}}$ & $0.50 \pm 0.01^{\mathrm{A}}$ & $0.51 \pm 0.01^{\mathrm{A}}$ \\
\hline Stearic acid (C18:0) & $10.96 \pm 0.05^{B}$ & $10.40 \pm 0.02^{\mathrm{C}}$ & $11.00 \pm 0.14^{B}$ & $10.34 \pm 0.04^{C}$ & $11.45 \pm 0.09^{A}$ & $11.38 \pm 0.11^{\mathrm{A}}$ \\
\hline Oleic acid (C18:1) & $48.21 \pm 0.06^{\mathrm{B}}$ & $47.49 \pm 0.17^{\mathrm{D}}$ & $47.46 \pm 0.16^{\mathrm{D}}$ & $47.55 \pm 0.05^{\mathrm{D}}$ & $47.93 \pm 0.08^{\mathrm{C}}$ & $48.56 \pm 0.16^{A}$ \\
\hline Linoleic acid (C18:2, n-6) & $9.36 \pm 0.08^{C}$ & $11.61 \pm 0.23^{\mathrm{A}}$ & $11.33 \pm 0.21^{\mathrm{B}}$ & $11.77 \pm 0.02^{\mathrm{A}}$ & $9.52 \pm 0.05^{\mathrm{C}}$ & $9.43 \pm 0.10^{C}$ \\
\hline Linolenic acid (C18:3, n-3) & $0.42 \pm 0.01^{\mathrm{C}}$ & $0.64 \pm 0.03^{\mathrm{A}}$ & $0.61 \pm 0.03^{B}$ & $0.65 \pm 0.01^{\mathrm{A}}$ & $0.42 \pm 0.01^{c}$ & $0.41 \pm 0.01^{\mathrm{C}}$ \\
\hline Arachidic acid (C20:0) & $0.16 \pm 0.01^{\mathrm{A}}$ & $0.15 \pm 0.00^{B}$ & $0.16 \pm 0.01^{\mathrm{A}}$ & $0.15 \pm 0.00^{B}$ & $0.16 \pm 0.01^{\mathrm{A}}$ & $0.17 \pm 0.00^{A}$ \\
\hline Eicosenoic acid (C20:1) & $1.04 \pm 0.01^{B}$ & $0.96 \pm 0.02^{\mathrm{E}}$ & $0.99 \pm 0.01^{\mathrm{D}}$ & $0.98 \pm 0.00^{\mathrm{D}}$ & $1.03 \pm 0.01^{c}$ & $1.06 \pm 0.01^{\mathrm{A}}$ \\
\hline $\begin{array}{l}\text { Eicosatrienoic acid } \\
\text { (C20:4, }-6)\end{array}$ & $0.19 \pm 0.01^{B}$ & $0.40 \pm 0.05^{\mathrm{A}}$ & $0.40 \pm 0.05^{\mathrm{A}}$ & $0.42 \pm 0.01^{\mathrm{A}}$ & $0.20 \pm 0.01^{B}$ & $0.20 \pm 0.01^{B}$ \\
\hline SFA & $37.43 \pm 0.10^{A B}$ & $35.61 \pm 0.11^{\mathrm{D}}$ & $36.10 \pm 0.24^{C}$ & $35.37 \pm 0.04^{D}$ & $37.69 \pm 0.12^{A}$ & $37.16 \pm 0.26^{B}$ \\
\hline MUFA & $52.60 \pm 0.06^{A}$ & $51.75 \pm 0.20^{C}$ & $51.56 \pm 0.19^{C}$ & $51.78 \pm 0.06^{\mathrm{C}}$ & $52.17 \pm 0.08^{\mathrm{B}}$ & $52.81 \pm 0.17^{\mathrm{A}}$ \\
\hline PUFA & $9.97 \pm 0.09^{C}$ & $12.65 \pm 0.30^{A B}$ & $12.34 \pm 0.28^{B}$ & $12.84 \pm 0.02^{A}$ & $10.14 \pm 0.06^{C}$ & $10.03 \pm 0.11^{\mathrm{C}}$ \\
\hline EFA & $9.97 \pm 0.09^{C}$ & $12.65 \pm 0.30^{\mathrm{AB}}$ & $12.34 \pm 0.28^{B}$ & $12.84 \pm 0.02^{A}$ & $10.14 \pm 0.06^{C}$ & $10.03 \pm 0.11^{\mathrm{C}}$ \\
\hline UFA & $62.57 \pm 0.10^{\mathrm{CD}}$ & $64.39 \pm 0.11^{\mathrm{A}}$ & $63.90 \pm 0.24^{B}$ & $64.63 \pm 0.04^{A}$ & $62.31 \pm 0.12^{\mathrm{D}}$ & $62.84 \pm 0.26^{\mathrm{C}}$ \\
\hline UFA/SFA & $1.67 \pm 0.01^{\mathrm{CD}}$ & $1.81 \pm 0.01^{\mathrm{A}}$ & $1.77 \pm 0.02^{B}$ & $1.83 \pm 0.01^{\mathrm{A}}$ & $1.65 \pm 0.01^{D}$ & $1.69 \pm 0.02^{C}$ \\
\hline EFA/UFA & $0.16 \pm 0.00^{C}$ & $0.20 \pm 0.01^{\mathrm{AB}}$ & $0.19 \pm 0.01^{\mathrm{B}}$ & $0.20 \pm 0.00^{A}$ & $0.16 \pm 0.00^{c}$ & $0.16 \pm 0.00^{C}$ \\
\hline$n-3$ & $0.42 \pm 0.01^{\mathrm{C}}$ & $0.64 \pm 0.03^{A}$ & $0.61 \pm 0.03^{\mathrm{B}}$ & $0.65 \pm 0.01^{\mathrm{A}}$ & $0.42 \pm 0.01^{c}$ & $0.41 \pm 0.01^{\mathrm{C}}$ \\
\hline$n-6$ & $9.55 \pm 0.08^{C}$ & $12.01 \pm 0.28^{\mathrm{AB}}$ & $11.73 \pm 0.26^{\mathrm{B}}$ & $12.19 \pm 0.02^{\mathrm{A}}$ & $9.72 \pm 0.06^{\mathrm{C}}$ & $9.62 \pm 0.10^{C}$ \\
\hline$n-6 / n-3$ & $22.61 \pm 0.24^{B}$ & $18.89 \pm 0.43^{\mathrm{D}}$ & $19.46 \pm 0.42^{C}$ & $18.76 \pm 0.20^{\mathrm{D}}$ & $23.38 \pm 0.31^{A}$ & $23.74 \pm 0.20^{A}$ \\
\hline
\end{tabular}

${ }^{11}$ Treatments: CON (control), $=0.014 \%$ sodium nitrite, CON1 (control1), no sodium nitrite and purple-fleshed sweet potato powder combination; PP1, no sodium nitrite and $0.5 \%$ purple-fleshed sweet potato powder; PP2, no sodium nitrite and $1 \%$ purple-fleshed sweet potato powder; SP1, $0.011 \%$ sodium nitrite and $0.5 \%$ purple-fleshed sweet potato powder combination; SP2, $0.011 \%$ sodium nitrite and $1 \%$ purple-fleshed sweet potato powder combination.

${ }^{A-F}$ Means in the same column within the same aging period with different letters are significantly different $(p<0.05)$.

SFA, saturated fatty acids; MUFA, monounsaturated fatty acids; PUFA, polyunsaturated fatty acids; EFA, essential fatty acids; UFA, unsaturated fatty acids.

lower cholesterol [30]. Adding PP to sausages also increased in the amount of linolenic acid in the sausages in the present study. This might be due to the high abundance of linolenic acid in purple sweet potatoes [20].

Adding PP caused changes in the levels of several amino acids in the pork sausages (Table 5), even though the total protein contents did not significantly differ $(p>0.05)$. The abundance of free glutamic acid was high. Glutamic acid is associated with the flavor called umami, which has a slightly sweet and sour taste [31]. The samples with purple-fleshed sweet potatoes contained significantly more glutamic acid, alanine, histidine, lysine, and arginine, and lower ratios of aspartic acid and cysteine $(p<0.05)$. Purple sweet potatoes are abundant in aspartic acid, glutamic acid, serine, alanine, valine, and other amino acids [20,32]. Changes in the levels of glutamic acid in the samples with PP can be attributed to the high amounts of similar amino acids extant in purple sweet potatoes. Levels of glutamic acid and alanine were higher in the SP2 than in the CON group $(p<0.05)$. 
Table 5. Protein and amino acid composition of cooked pork sausages containing two different percentages of purple sweet potato combined with nitrite

\begin{tabular}{|c|c|c|c|c|c|c|}
\hline & & & Tre & $\mathrm{ts}^{1)}$ & & \\
\hline & CON & CON1 & PP1 & PP2 & SP1 & SP2 \\
\hline Protein & $17.76 \pm 0.58$ & $17.40 \pm 0.16$ & $18.09 \pm 0.48$ & $17.79 \pm 0.38$ & $18.28 \pm 1.14$ & $17.99 \pm 0.23$ \\
\hline Aspartic acid & $9.38 \pm 0.12^{A}$ & $9.22 \pm 0.00^{\mathrm{A}}$ & $7.40 \pm 0.09^{B}$ & $6.82 \pm 0.93^{\mathrm{B}}$ & $7.50 \pm 0.20^{B}$ & $7.51 \pm 0.08^{\mathrm{B}}$ \\
\hline Threonine & $4.65 \pm 0.00$ & $4.59 \pm 0.00$ & $4.60 \pm 0.06$ & $4.65 \pm 0.10$ & $4.67 \pm 0.02$ & $4.50 \pm 0.01$ \\
\hline Serine & $3.87 \pm 0.10$ & $3.75 \pm 0.00$ & $4.06 \pm 0.18$ & $4.07 \pm 0.21$ & $4.07 \pm 0.14$ & $4.08 \pm 0.18$ \\
\hline Glutamic acid & $14.91 \pm 0.43^{\mathrm{B}}$ & $14.77 \pm 0.00^{B}$ & $16.00 \pm 0.01^{\mathrm{A}}$ & $16.11 \pm 0.14^{\mathrm{A}}$ & $15.67 \pm 0.30^{A}$ & $15.59 \pm 0.30^{A}$ \\
\hline Proline & $4.29 \pm 0.06$ & $4.40 \pm 0.00$ & $4.43 \pm 0.26$ & $4.45 \pm 0.05$ & $4.42 \pm 0.28$ & $4.58 \pm 0.16$ \\
\hline Glycine & $4.89 \pm 0.25$ & $4.81 \pm 0.00$ & $5.13 \pm 0.05$ & $4.95 \pm 0.11$ & $4.97 \pm 0.02$ & $5.10 \pm 0.07$ \\
\hline Alanine & $5.86 \pm 0.09^{B}$ & $5.85 \pm 0.00^{B}$ & $6.18 \pm 0.06^{A}$ & $6.25 \pm 0.15^{A}$ & $6.21 \pm 0.11^{\mathrm{A}}$ & $6.17 \pm 0.03^{A}$ \\
\hline Cysteine & $1.37 \pm 0.11^{\mathrm{A}}$ & $1.20 \pm 0.00^{B}$ & $0.00 \pm 0.00^{\mathrm{D}}$ & $0.21 \pm 0.00^{C}$ & $0.00 \pm 0.00^{\mathrm{D}}$ & $0.00 \pm 0.00^{\mathrm{D}}$ \\
\hline Valine & $5.48 \pm 0.05$ & $5.54 \pm 0.00$ & $5.58 \pm 0.06$ & $5.67 \pm 0.16$ & $5.73 \pm 0.01$ & $5.68 \pm 0.18$ \\
\hline Methionine & $2.40 \pm 0.74$ & $2.94 \pm 0.00$ & $2.71 \pm 0.02$ & $2.59 \pm 0.23$ & $2.51 \pm 0.62$ & $2.76 \pm 0.19$ \\
\hline Isoleucine & $5.08 \pm 0.09$ & $5.06 \pm 0.00$ & $5.11 \pm 0.07$ & $5.24 \pm 0.22$ & $5.34 \pm 0.13$ & $5.18 \pm 0.18$ \\
\hline Leucine & $8.40 \pm 0.02$ & $8.42 \pm 0.00$ & $8.50 \pm 0.04$ & $8.64 \pm 0.17$ & $8.68 \pm 0.06$ & $8.61 \pm 0.18$ \\
\hline Tyrosine & $3.32 \pm 0.28$ & $3.55 \pm 0.00$ & $3.51 \pm 0.05$ & $3.42 \pm 0.16$ & $3.31 \pm 0.23$ & $3.55 \pm 0.15$ \\
\hline Phenylalanine & $4.17 \pm 0.01$ & $4.19 \pm 0.00$ & $4.27 \pm 0.02$ & $4.35 \pm 0.10$ & $4.29 \pm 0.04$ & $4.31 \pm 0.06$ \\
\hline Histidine & $4.85 \pm 0.09^{B}$ & $4.68 \pm 0.00^{C}$ & $5.03 \pm 0.08^{A}$ & $5.12 \pm 0.04^{A}$ & $5.02 \pm 0.05^{\mathrm{A}}$ & $4.98 \pm 0.08^{\mathrm{AE}}$ \\
\hline Lysine & $9.08 \pm 0.02^{\mathrm{BC}}$ & $9.04 \pm 0.00^{C}$ & $9.29 \pm 0.04^{A}$ & $9.32 \pm 0.06^{A}$ & $9.30 \pm 0.13^{A}$ & $9.21 \pm 0.01^{\mathrm{AE}}$ \\
\hline Ammonia & $1.53 \pm 0.01$ & $1.52 \pm 0.00$ & $1.54 \pm 0.12$ & $1.58 \pm 0.09$ & $1.66 \pm 0.06$ & $1.60 \pm 0.01$ \\
\hline Arginine & $6.52 \pm 0.11^{\mathrm{B}}$ & $6.47 \pm 0.00^{\mathrm{B}}$ & $6.72 \pm 0.07^{A}$ & $6.71 \pm 0.10^{A}$ & $6.70 \pm 0.00^{A}$ & $6.63 \pm 0.02^{A \mathrm{E}}$ \\
\hline FAA & $14.91 \pm 0.43^{B}$ & $14.77 \pm 0.00^{B}$ & $16.00 \pm 0.01^{A}$ & $16.11 \pm 0.14^{A}$ & $15.67 \pm 0.30^{A}$ & $15.59 \pm 0.30^{A}$ \\
\hline STAA & $19.26 \pm 0.45$ & $19.00 \pm 0.00$ & $19.96 \pm 0.35$ & $19.92 \pm 0.15$ & $19.91 \pm 0.26$ & $19.85 \pm 0.30$ \\
\hline SAA & $3.78 \pm 0.84$ & $4.14 \pm 0.00$ & $2.71 \pm 0.02$ & $2.63 \pm 0.00$ & $2.51 \pm 0.62$ & $2.76 \pm 0.19$ \\
\hline AAA & $7.49 \pm 0.26$ & $7.73 \pm 0.00$ & $7.77 \pm 0.06$ & $7.77 \pm 0.06$ & $7.60 \pm 0.19$ & $7.85 \pm 0.21$ \\
\hline BAA & $31.08+0.97$ & $32.43+0.00$ & $32.92+0.04$ & $33.09+0.22$ & $32.88+0.71$ & $33.06+0.66$ \\
\hline EAA & $50.60 \pm 0.68$ & $50.93 \pm 0.00$ & $51.79 \pm 0.04$ & $52.29 \pm 0.70$ & $52.20 \pm 0.27$ & $51.84 \pm 0.69$ \\
\hline TAA & 100 & 100 & 100 & 100 & 100 & 100 \\
\hline
\end{tabular}

${ }^{11}$ Treatments: CON (control), $0.014 \%$ sodium nitrite; CON1 (control1), no sodium nitrite and purple-fleshed sweet potato powder combination; PP1 = no sodium nitrite and $0.5 \%$ purple-fleshed sweet potato powder; PP2, no sodium nitrite and $1 \%$ purple-fleshed sweet potato powder; SP1, $0.011 \%$ sodium nitrite and $0.5 \%$ purple-fleshed sweet potato powder combination; SP2, $0.011 \%$ sodium nitrite and $1 \%$ purple-fleshed sweet potato powder combination.

${ }^{A-D}$ Means in the same column within the same aging period with different letters are significantly different $(p<0.05)$.

FAA, flavorous amino acid; STAA, sweet taste amino acid; SAA, sulfur-containing amino acid; AAA, aromatic amino acid; BAA, bitter amino acid; EAA, essential amino acid; TAA total amino acid.

\section{CONCLUSION}

The inclusion of $1 \% \mathrm{PP}$ with $0.011 \%$ sodium nitrite as a colorant seemed to confer desirable subjective and objective qualities on sausages. The residual nitrite content in sausages with added PP decreased over time in storage. The addition of $1 \%$ PP produced major changes in the fatty acid profiles of the sausages, reduced the ratios of SFA and MUFA, and increased PUFA levels. Adding $\mathrm{PP}$ also tended to increase the content of flavorous amino acids. The fatty acid composition was comparable between the SP2 and CON groups, but the SP2 groups contained more flavorous and sweet-tasting amino acids than the CON group. Therefore, including up to $1 \%$ of $\mathrm{PP}$ along with $0.011 \% \mathrm{NaNO}_{2}$ could serve as a natural colorant for pork sausages without any detrimental effects on quality. We also found that $20 \% \mathrm{PP}$ might be able to replace $\mathrm{NaNO}_{2}$. However, further investi- 
gation is needed to determine the effects of partially substituting $\mathrm{NaNO}_{2}$ with $\mathrm{PP}$ on the oxidative and microbiological stability of meat products.

\section{REFERENCES}

1. Weiss J, Gibis M, Schuh V, Salminen H. Advances in ingredient and processing systems for meat and meat products. Meat Sci. 2010;86:196-213. https://doi.org/10.1016/j.meatsci.2010.05.008

2. Yim DG, Ali M, Nam KC. Comparison of meat quality traits in salami added by nitrate-free salts or nitrate pickling salt during ripening. Food Sci Anim Resour. 2020;40:11-20. https:// doi.org/10.5851/kosfa.2019.e61

3. Marco A, Navarro JL, Flores M. The influence of nitrite and nitrate on microbial, chemical and sensory parameters of slow dry fermented sausage. Meat Sci. 2006;73:660-73. https://doi. org/10.1016/j.meatsci.2006.03.011

4. Alahakoon AU, Jayasena DD, Ramachandra S, Jo C. Alternatives to nitrite in processed meat: up to date. Trends Food Sci Technol. 2015;45:37-49. https://doi.org/10.1016/j.tifs.2015.05.008

5. Han J, Rhee KS. Antioxidant properties of selected oriental non-culinary/nutraceutical herb extracts as evaluated in raw and cooked meat. Meat Sci. 2005;70:25-33. https://doi.org/10.1016/ j.meatsci.2004.11.017

6. Effah-Manu L, Oduro I, Addo A. Effect of dextrinized sweet potatoes on the physicochemical and sensory quality of infra-red dried mango leather. J Food Process Technol. 2013;4:1000230. https://doi.org/10.4172/2157-7110.1000230

7. Islam S, Yoshimoto M, Terahara N, Yamakawa O. Anthocyanin compositions in sweetpotato (Ipomoea batatas L.) leaves. Biosci Biotechnol Biochem. 2002;66:2483-6. https://doi. org/10.1271/bbb.66.2483

8. Teow CC, Truong VD, McFeeters RF, Thompson RL, Pecota KV, Yencho GC. Antioxidant activities, phenolic and $\beta$-carotene contents of sweet potato genotypes with varying flesh colours. Food Chem. 2007;103:829-38. https://doi.org/10.1016/j.foodchem.2006.09.033

9. Tang C, Sun J, Zhou B, Jin C, Liu J, Kan J, et al. Effects of polysaccharides from purple sweet potatoes on immune response and gut microbiota composition in normal and cyclophosphamide treated mice. Food Funct. 2018;9:937-50. https://doi.org/10.1039/C7FO01302G

10. Tsukui A, Murakami T, Shiina R, Hayashi K. Effect of alcoholic fermentation on the stability of purple sweet potato anthocyanins. Food Sci Technol Res. 2002;8:4-7. https://doi. org/10.3136/fstr.8.4

11. Joo ST. Determination of water-holding capacity of porcine musculature based on released water method using optimal load. Korean J Food Sci Anim Resour. 2018;38:823-8. https://doi. org/10.5851/kosfa.2018.e18

12. Pearson D. The chemical analysis of foods. 7th ed. New York, NY: Churchill Livingston; 1976. p. 386.

13. AOAC [Association of Official Analytical Chemists]. Official methods of analysis. 15th ed. Washington, DC: AOAC; 1990.

14. Folch J, Lee M, Sloane-Stanley GH. A simple method for the isolation and purification of total lipids from animal tissues. J Biol Chem. 1957;226:497-507.

15. Bligh EG, Dyer WJ. A rapid method of total lipid extraction and purification. Can J Biochem Physiol. 1959;37:911-7. https://doi.org/10.1139/o59-099

16. Bidlingmeyer BA, Cohen SA, Tarvin TL. Rapid analysis of amino acids using pre-column derivatization. J Chromatogr B: Biomed Sci Appl. 1984;336:93-104. https://doi.org/10.1016/ 
S0378-4347(00)85133-6

17. AMSA [American Meat Science Association]. Research guidelines for cookery, sensory evaluation and instrumental tenderness measurements of fresh meat. Chicago, IL: AMSA; 1995.

18. Meilgaard M, Civille GV, Carr BT. Sensory evaluation techniques. 2nd ed. Boca Raton, FL: CRC Press; 1991.

19. SAS. SAS/STAT software for PC. Release 6.12. Cary, NC: SAS Institute; 1998.

20. Kim SY, Ryu CH. Studies on the nutritional components of purple sweet potato. Korean J Food Sci Technol. 1995;27:819-25.

21. Bae SM, Cho MG, Jeong JY. The effects of addition timing of $\mathrm{NaCl}$ and sodium tripolyphosphate and cooking rate on pink color in cooked ground chicken breasts. Food Sci Anim Resour. 2020;40:231-41. https://doi.org/10.5851/kosfa.2020.e7

22. Dutra MP, Cardoso GP, Ramos EM, Ramos A de LS, Pinheiro ACM, Fontes PR. Technological and sensory quality of restructured low-fat cooked ham containing liquid whey. Ciênc Agrotecnol. 2012;36:86-92. https://doi.org/10.1590/S1413-70542012000100011

23. Lee N,Jo YJ, Yook HS. Quality characteristics and antioxidant activities of sausages made from a mixture of purple sweet potato powder and purple sweet potato pigment.J Korean Soc Food Sci Nutr. 2015;44:1317-24. https://doi.org/10.3746/jkfn.2015.44.9.1317

24. Jin SK, Kim YJ, Park JH, Hur IC, Nam SH, Shin D. Effects of purple-fleshed sweet potato (Ipomoera batatas Cultivar Ayamurasaki) powder addition on color and texture properties and sensory characteristics of cooked pork sausages during storage. Asian-Australas J Anim Sci. 2012;25:1329-37.https://doi.org/10.5713/ajas.2012.12125

25. Bhosale SS, Biswas AK, Sahoo J, Chatli MK, Sharma DK, Sikka SS. Quality evaluation of functional chicken nuggets incorporated with ground carrot and mashed sweet potato. Food Sci Technol Int. 2011;17:233-9. https://doi.org/10.1177/1082013210382339

26. Pérez-Sira E. Characterization of starch isolated from plantain (Musa paradisiaca normalis). Starch. 1997;49:45-9. https://doi.org/10.1002/star.19970490202

27. Warris PD. Meat quality. In: Meat science: an introductory text. 2nd ed. Wallingford: CAB International; 2010.p. 77-96.

28. Marco A, Navarro JL, Flores M. The influence of nitrite and nitrate on microbial, chemical and sensory parameters of slow dry fermented sausage. Meat Sci. 2006;73:660-73. https://doi. org/10.1016/j.meatsci.2006.03.011

29. Hu FB, Manson JE, Willett WC. Types of dietary fat and risk of coronary heart disease: a critical review.J Am Coll Nutr. 2001;20:5-19. https://doi.org/10.1080/07315724.2001.10719008

30. Grundy SM, Bilheimer CD, Blackburn H, Brown WV, Kwiterovich POJ, Mattson F. Rationale of the diet-heart statement of the American Heart Association. Report of Nutrition Committee. Nutr Today. 1982;17:16-20.

31. Maga JA. Umami flavour of meat. In: Shahidi F, editor. Flavor of meat products and seafood. London: C hapman \& Hall; 1998. p. 197-216.

32. Mu TH, Tan SS, Xue YL. The amino acid composition, solubility and emulsifying properties of sweet potato protein. Food chem. 2009;112:1002-5. https://doi.org/10.1016/j.foodchem.2008.07.012 